\title{
The Mail Fraud Statute: An Argument for Repeal by Implication
}

\author{
Todd E. Molz†
}

Think twice next time you drop a letter in the mail: you may be committing a crime. The federal mail fraud statute ${ }^{1}$ captures almost every form of deceptive behavior that uses the mail, ${ }^{2}$ so if you have ever lied in a letter to get money or property, it's time to turn yourself in. You could be sentenced to five years in a federal prison and a fine. ${ }^{3}$

The expansive language of the mail fraud statute creates its broad reach. The text of the statute makes it a crime for anyone "having devised or intending to devise any scheme or artifice to defraud, or for obtaining money or property by means of false or fraudulent pretenses, representations, or promises," to use the mail or a private carrier. ${ }^{4}$ Thus, the statute reaches far beyond the simple "fraud" that its name suggests to encompass any attempts to use the mail to obtain money or property by deception. Indeed, the Supreme Court has explicitly declared that the statute is not limited to the definition of common law fraud, ${ }^{5}$ a definition that is itself extremely broad. ${ }^{6}$

† B.A. 1994, Middlebury College; J.D. Candidate 1997, The University of Chicago.

118 USC $\$ 1341$ (1994 \& Supp 1996). This Comment's discussion of mail fraud applies equally to the wire fraud statute, 18 USC $\$ 1343$ (1994 \& Supp 1996). The two statutes are almost identical, the primary difference being that jurisdiction under the mail fraud statute is triggered when a person uses the mail system or a private carrier, while the wire fraud statute applies when a person "transmits or causes to be transmitted by means of wire, radio, or television communication in interstate or foreign commerce any writings, signs, signals, pictures, or sounds for the purpose of executing such scheme or artifice ...." See 18 USC $\$ 1343$.

${ }^{2}$ See John C. Coffee, Jr., From Tort to Crime: Some Reflections on the Criminalization of Fiduciary Breaches and the Problematic Line Between Law and Ethics, $19 \mathrm{Am}$ Crim L Rev 117, 119 (1981) (citing jury instruction, upheld by the D.C. Circuit, that "seems to equate dishonesty with the criminal offense of mail fraud"). See also Post $v$ United States, 407 F2d 319, 329 (DC Cir 1968) (Jury instruction correctly defined purposeful breach of a fiduciary duty as a type of dishonesty covered by the mail fraud statute.).

${ }_{3} 18$ USC $\S 1341$. See also Federal Sentencing Guidelines, 18 USC $\S \S 2 C 1.7,2 F 1.1$ (1994).

4 18 USC § 1341.

5 Durland $v$ United States, 161 US 306, 312-13 (1896) (addressing and rejecting the argument that the statute is limited to the reach of common law "false pretenses").

"See Weiss $v$ United States, 122 F2d 675, 681 (5th Cir 1941) ("The law does not define fraud; it needs no definition; it is as old as falsehood and as versable as human inge- 
Courts $^{7}$ and commentators ${ }^{8}$ alike have expressed concern about the comprehensive scope of the mail fraud statute. Two fundamental problems flow from the statute's breadth. First, prosecutors, aided by courts, use the statute to fill gaps in the criminal law left by Congress, ${ }^{9}$ despite the Constitution's declaration that "all legislative powers" therein granted are vested in the Congress. ${ }^{10}$ Second, the statute fails to provide citizens with adequate notice as to what conduct it outlaws. One of the basic principles of the rule of law is that the state must provide clear notice of the illegality of a course of action before depriving an individual of his liberty. ${ }^{11}$

Courts have disregarded numerous commentators' proposals to limit the mail fraud statute. ${ }^{12}$ Courts have properly ignored

nuity."); Joseph Story, 1 Equity Jurisprudence \$ 187 at 199 (Little, Brown 11th ed 1873) ("Fraud ... includes all acts ... which involve a breach of legal or equitable duty ... and [which] are injurious to another, or by which an undue and unconscientious advantage is taken of another.") (citations omitted).

' See Emery $v$ American General Finance, Inc, 71 F3d 1343, 1346 (7th Cir 1995) ("The language of the mail-fraud statute is very broad, and concern has repeatedly been expressed that it not be given too vague and encompassing a scope by judicial interpretation.") (citations omitted); United States v Barta, 635 F2d 999, 1001 (2d Cir 1980) ("[W]e are asked to construe two seemingly limitless provisions, the mail and wire fraud statutes.") (footnotes omitted).

${ }^{8}$ See, for example, Coffee, 19 Am Crim L Rev at 126-28 (cited in note 2) ("In light of the inherent overbreadth of [the] prevailing interpretation of mail and wire fraud statutes, it is hardly surprising that several recent commentators have raised the spectre of overcriminalization."); Daniel J. Hurson, Limiting the Federal Mail Fraud Statute-A Legislative Approach, 20 Am Crim L Rev 423, 424-26 (1983) (observing that the statute "has been expansively interpreted to invite federal prosecution of virtually every type of untoward activity known to man") (citations omitted).

${ }^{9}$ Coffee, $19 \mathrm{Am}$ Crim L Rev at 126 (cited in note 2) ("Among prosecutors, a wellknown maxim says 'when in doubt, charge mail fraud."'). See also Dan M. Kahan, Is Chevron Relevant to Criminal Law?, 110 Harv L Rev 469, 480 (1996) (Courts' current treatment of statutes such as the mail fraud statute "effectively transfers delegated lawmaking authority to individual prosecutors.").

${ }^{10}$ US Const, Art I, $\$ 1$.

${ }^{11}$ See United States $v$ Batchelder, 442 US 114, 123 (1979), quoting Lanzetta $v$ New Jersey, 306 US 451, 453 (1939) ("It is a fundamental tenet of due process that '[no] one may be required at peril of life, liberty or property to speculate as to the meaning of penal statutes."); United States $v$ Harriss, 347 US 612, 617 (1954) (A criminal statute must "give a person of ordinary intelligence fair notice that his contemplated conduct is forbidden by the statute.").

${ }_{12}$ Many critics of the mail fraud statute argue for a legislative response. See Ellen $\mathrm{S}$. Podgor, Mail Fraud: Opening Letters, 43 SC L Rev 223, 269 (1992) ("This restructuring [of the mail fraud statute] needs to be an action of our legislature, as opposed to the judiciary."); Coffee, $19 \mathrm{Am}$ Crim $L$ Rev at 166-72 (cited in note 2) (calling for a legislative response to the rapid change in the meaning of the federal fraud statutes); Hurson, $20 \mathrm{Am}$ Crim L Rev at 457-58 (cited in note 8) (proposing a specific definition of "scheme to defraud" for Congress to insert in the mail fraud statute); and Geraldine Szott Moohr, Mail Fraud and the Intangible Rights Doctrine: Someone to Watch Over Us, 31 Harv J Leg 153, 200-01 (1994) (proposing a new mail fraud statute). Independent of their relative merits, these suggestions all suffer from one fatal defect: Congress will never rein in the mail 
these proposals because the commentators mistakenly suggest limiting the statute's scope by providing a positive theory of mail fraud. ${ }^{13}$ To define the limits of mail fraud, however, would destroy the statute's ability to adapt and thereby capture new forms of fraud. ${ }^{14}$ This adaptability is important because crime assumes many forms, criminals can find and exploit statutory loopholes, and Congress has limited resources with which to draft, debate, and enact criminal statutes. ${ }^{15}$ Indeed, the broad language of the mail fraud statute allows courts to adapt the statute to new forms of fraud, thereby deterring criminals from finding and exploiting loopholes and, by delegating lawmaking power to courts, lowering the cost of legislating for Congress. ${ }^{16}$

At this point, it is important to distinguish "good" gapfilling from "bad" gapfilling. Broad statutes such as the mail fraud statute enable prosecutors and courts to fill gaps in the criminal law. Such gapfilling is good when the illicit activity is a new form of fraud that Congress has yet to consider. For example, before Congress passed the credit card fraud statute, prosecutors and courts used the mail fraud statute to prosecute such fraud. As Chief Justice Burger noted, the mail fraud statute acts as a "stopgap device to deal on a temporary basis with the new phenomenon, until [Congress can pass] particularized legislation."17 This form of gapfilling improves criminal law because it deters criminals from engaging in illicit behavior and enables courts to block new forms of fraud quickly and easily.

In contrast, "bad" gapfilling occurs when prosecutors and courts use the mail fraud statute to fill gaps in existing statutes, undermining the congressional judgment embodied in those statutory gaps. Once Congress has passed "particularized legislation," the mail fraud statute is no longer needed to act as a stopgap. Suppose Congress enacts a credit card statute with a requirement that the fraud be for at least five thousand dollars. Congress has made a specific judgment that credit card fraud for

fraud statute because it wants to preserve its status as a gapfiller. See text accompanying notes 99-102.

${ }^{13}$ A positive theory of mail fraud attempts to define mail fraud in terms of a limited set of probibited activities. In contrast, this Comment defines mail fraud only in negative terms, that is, what conduct is not covered. See text accompanying notes 112-25.

14 John C. Coffee, Jr., The Metastasis of Mail Fraud: The Continuing Scope of the "Evolution" of a White-Collar Crime, 21 Am Crim L Rev 1, 27 (1983) ("The practical strength of the mail fraud statute is also its conceptual weakness.").

s. Kahan, 110 Harv L Rev at 474-75 (cited in note 9).

${ }^{16}$ Dan M. Kahan, Lenity and Federal Common Law Crimes, 1994 S Ct Rev 343, 377. But see United States $v$ Hudson and Goodwin, 11 US (7 Cranch) 32, 34 (1812) (Congress alone has the power to create criminal law.).

${ }^{17}$ United States $v$ Maze, 414 US 395, 405-06 (1974) (Burger dissenting). 
amounts below five thousand dollars does not merit the attention of federal authorities. But if a prosecutor now elects to prosecute a case of credit card fraud involving three hundred dollars under the mail fraud statute, she has undone that congressional judgment. She has used the mail fraud statute to fill a statutory gap intentionally created by Congress. Such gapfilling is bad because it blocks the ability of Congress to place certain conduct beyond the reach of federal criminal law.

This Comment seeks to preserve the strength of the mail fraud statute-its ability to reach new forms of fraud-while mitigating its weaknesses by using a tool of statutory interpretation: repeal by implication. When Congress passes a criminal statute governing a particular form of conduct, such as credit card fraud, repeal by implication dictates that the mail fraud statute has been implicitly repealed for cases of credit card fraud.

Repeal by implication does not depend upon a positive theory of mail fraud in order to limit the mail fraud statute. Instead, it utilizes subsequent statutes to define what mail fraud is not. This restraint would allow the mail fraud statute to continue to adapt to and capture new forms of fraud, but would also create pockets in the criminal law governed exclusively by subsequent statutes. Repeal by implication is superior to current approaches to the mail fraud statute because it would reduce the cost to Congress of stopping prosecutors from bad gapfilling, restrict judicial and prosecutorial discretion, enhance notice of proscribed criminal conduct, and preserve the mail fraud statute as a gapfiller.

Part I of this Comment reviews four cases: the first three cases illustrate the incoherence of the current approach to the mail fraud statute; the last case then illustrates one court's attempt to apply repeal by implication. Part II argues that courts fundamentally misunderstand the mail fraud statute, creating the confusion in the current law. Part III first makes the case for repeal by implication and addresses how to determine the scope of an implicit repeal; it then concludes by examining the caselaw and demonstrating that it accommodates repeal by implication.

\section{THE CURRENT APPROACH TO THE MAII FraUd STATUTE}

This Part analyzes four cases to show how courts apply the mail fraud statute. Each of the first three cases highlights different defects in the current approach. The first case illustrates how courts allow prosecutors to use the mail fraud statute to ignore Congress's considered judgment in enacting criminal statutes. The second case shows how the current approach creates sense- 
less inconsistency in federal criminal law. The third case reveals the current approach's inability to generate clear precedent for lower courts. Together, these three cases demonstrate the incoherence of the current approach to the mail fraud statute. The final case illustrates an insightful application of the repeal by implication approach.

\section{A. Ignoring Congress's Considered Judgment}

Justice Blackmun's majority opinion in Dowling $v$ United States $^{18}$ offers a powerful argument for deferring to Congress's considered judgment. In the lower court, the defendant had been convicted of violating both the mail fraud statute and the National Stolen Property Act ${ }^{19}$ for the sale and shipment of illegally bootlegged audiotapes. The Supreme Court, however, threw out the conviction under the National Stolen Property Act on the grounds that the broader criminal statute did not apply when there existed a more specific statute that established a more refined, less onerous penalty structure ${ }^{20}$ in this case the Copyright Act. ${ }^{21}$ Despite the Court's own holding, the mail fraud convictions were never questioned.

The Court made a strong argument for relying exclusively on the more specific statute. It pointed out that "the history of the criminal infringement provisions of the Copyright Act reveals a good deal of care on Congress' part before subjecting copyright infringement to serious criminal penalties." ${ }^{22}$ To apply the National Stolen Property Act would "presume[ ] congressional adoption of an indirect but blunderbuss solution to a problem treated with precision when considered directly [by Congress]."23

The Court never addressed the mail fraud convictions, ${ }^{24}$ leaving one to wonder why the argument against application of the National Stolen Property Act should not also preclude application of the mail fraud statute. Like the National Stolen Property Act, the mail fraud statute imposes serious criminal penalties, and is a "blunderbuss solution," in that it offers an unrefined penalty structure. Further, it overrides the careful and considered structure of the Copyright Act. Yet despite the striking

${ }^{18} 473$ US 207 (1985).

${ }^{19} 18$ USC $\S 2314$ (1994).

${ }^{20}$ Dowling, 473 US at 227-29.

2117 USC \& 506(a) (1994).

${ }^{22}$ Dowling, 473 US at 225.

${ }^{23}$ Id at 226.

${ }^{24}$ For unidentified reasons, the Court was concerned only with the charges under the National Stolen Property Act. Id at 209 n 1. 
similarities between the mail fraud statute and the National Stolen Property Act, the Court never questioned the application of the mail fraud statute. This omission is strange, for the Court's own reasoning suggests that the statute undermines Congress's "carefully considered approach" ${ }^{25}$ to copyright law.

\section{B. Senseless Inconsistency in Federal Criminal Law}

United States v Bryan ${ }^{26}$ illustrates how the current approach to the mail fraud statute leads to senseless inconsistency in federal criminal law. In Bryan, the Fourth Circuit rejected the misappropriation theory of liability under $\S 10(\mathrm{~b})$ of the Securities Exchange Act of $1934 .{ }^{27}$ Misappropriation theory imposes criminal liability on someone who trades on material nonpublic information that he gained by breaching a duty. ${ }^{28}$ The court rejected this theory because the theory failed to provide clear notice regarding the conduct it outlawed and thus created amorphous liability. The court reasoned that such amorphous liability would severely impair securities markets. ${ }^{29}$ It noted that "[t]he Supreme Court has repeatedly emphasized that the securities market demands certainty and predictability. ${ }^{230}$

In spite of this emphasis on the need for certainty in capital markets, however, the Bryan court proceeded to find the defendant guilty under the equally amorphous mail fraud statute. ${ }^{31}$

This result is strikingly incongruous. If the Fourth Circuit rejected misappropriation theory because of its potential to chill the fragile securities market, it should have rejected mail fraud for the very same reason. Broad and uncertain liability standards chill conduct-regardless of the statutory source. The Bryan court recognized this contradiction, but, strangely, was "not especially concerned with any inconsistency in the scope of fraud prohibited by these various statutes." 32

\footnotetext{
${ }^{25} \mathrm{Id}$ at 225.

${ }^{25} 58$ F3d 933 (4th Cir 1995).

${ }^{27} 15$ USC \& 78j(b) (1994).

${ }^{2 s}$ The Bryan court stated that misappropriation theory finds insider trading liability when someone: "(1) misappropriates material nonpublic information (2) by breaching a duty arising out of a relationship of trust and confidence and (3) uses that information in a securities transaction, (4) regardless of whether he owed any duties to the shareholders of the traded stock." 58 F3d at 944 (citations omitted).

${ }^{20}$ Id at 950-51.

${ }^{2}$ Id (internal quotation marks omitted).

${ }^{31}$ Id at 939-43.

${ }^{32}$ Id at 952.
} 
C. The Inability to Generate Useful Precedent

In United States $v$ Maze, the Supreme Court reached the right result, but for the wrong reasons. ${ }^{33}$ Since the case involved an area of conduct governed by a statute enacted after the mail fraud statute, the Court had an opportunity to invoke repeal by implication. Unfortunately, the Court followed the current approach to the mail fraud statute and, in so doing, offered little or no guidance to lower courts.

Maze stole his roommate's credit card and charged $\$ 301.85$ on it. ${ }^{34}$ Because the credit card fraud statute only reached frauds involving $\$ 5,000$ or more, ${ }^{35}$ the federal prosecutor could only charge Maze with mail fraud. ${ }^{36}$ The prosecutor argued that Maze had violated the mail fraud statute because he had devised a scheme to defraud and "knew that each merchant would cause the sales slips of the purchases to be delivered by mail to the [ ] bank which would in turn mail them to [his roommate] for payment." ${ }^{37}$ In addition, the prosecutor argued that the inherent delay of the mailings was essential to the success of Maze's scheme. ${ }^{38}$

The Supreme Court raised the standard for liability under the mail fraud statute to overturn Maze's convictions. It held that to violate the mail fraud statute, the mailing must be "for the purpose of executing the scheme, . . . but it is not necessary that . . . the use of the mails [be] an essential element [of the scheme]. ${ }^{n 9}$ In this case, the Court ruled, the mailings were not for the purpose of executing the scheme because the mailings actually "increased the probability that [he] would be detected and apprehended." ${ }^{30}$ As for the government's claim that the delay in the mailings led to the scheme's success, the Court stated that it was the distance, not the postal system, that caused the delay. ${ }^{41}$ By narrowing the scope of the mail fraud statute in this manner, the Court missed a perfect opportunity to invoke repeal by implication. ${ }^{42}$

\footnotetext{
3414 US 395 (1974).

${ }^{3}$ Id at $396,402 \mathrm{n} 6$.

35 15 USC $\$ 1644$ (1976).

s Maze, 414 US at 396.

${ }^{37}$ Id at 397.

₹ Id.

¥9 Id at 400-01, quoting Kann $v$ United States, 323 US 88, 94 (1944) and Pereira v United States, 347 US 1, 8 (1947) (internal quotations omitted and emphasis added).

${ }^{40}$ Maze, 414 US at 403.

"Id ("[T]he distance, and not the mail service, ... cause[d] the time lag in the physical transmission of such correspondence.") (citations omitted).

${ }^{2}$ The Supreme Court's approach in Maze stands in sharp contrast with the Court of
} 
Maze reveals yet another defect in the current approach: the Supreme Court's ad hoc method of interpreting the mail fraud statute. As the Court can decide only a few cases each year, it is critical that it provide clear guidance to lower courts. Yet shortly after the Court reversed the Maze conviction by requiring that the mails be used for the "purpose of executing the scheme," it replaced the Maze standard with a more lax requirement in Schmuck v United States. ${ }^{43}$ Because the Court rarely provides definitive guidance, prosecutors and defendants can cite multiple cases supporting their view of what satisfies the mailing elements of the mail fraud statute. ${ }^{44}$ While this defect alone may not be cause for alarm, when coupled with the other problems identified in this Part, it exposes the incoherence of the current approach.

Contrast this result with what would have happened if the Supreme Court had ruled that the credit card statute implicitly repealed the mail fraud statute. Lower courts would not apply the mail fraud statute to credit card fraud, a substantial limitation on the mail fraud statute would be in place, and the statute's gapfiller status would be preserved.

\footnotetext{
Appeals's approach. The Sixth Circuit observed that Congress had passed specific legislation governing credit card fraud, and concluded that courts should respect the judgments embodied in that statute: "[B]y establishing a jurisdictional floor of $\$ 5,000$ in the statute, Congress appears to have decided to make the aggravated misuse of credit cards, e.g., by organized criminals, a federal offense and to leave to local prosecution the casual or incidental misuse." United States v Maze, 468 F2d 529, 536 (6th Cir 1972), affd, 414 US 395 (1973). The Sixth Circuit, had it stopped here, would have offered an excellent example of repeal by implication. Unfortunately, the Sixth Circuit added the qualification "unless the offender makes a purposeful use of the mails to accomplish his scheme." Id. Believing the purposeful use of the mails to be a meaningful statutory requirement, the lower court thus mistakenly focused on the same issue as the Supreme Court.

${ }^{43} 489$ US 705, 713 (1989) (mailing of registration forms found to be central to the long-term success of an odometer scam). Schmuck continued the Supreme Court's vacillation on the rigor of this requirement. See also Kann, 323 US at 95 (The mail fraud statute reaches "only those limited instances in which the use of the mails is a part of the execution of the fraud."); Pereira, 347 US at 8 (mailing need not be essential to the scheme, only incidental) (citations omitted); Parr $v$ United States, 363 US 370, 392-93 (1960) (mailing of tax forms and credit card bill irrelevant to the success of the scheme, and therefore does not satisfy mailing requirement); and United States $v$ Sampson, 371 US $75,80-81$ (1962) (mailing after the perpetrators had received the money fulfilled the mailing requirement). See generally Matthew J. Effken, Note, The Mailing Element of the Federal Mail Fraud Statute: Schmuck v. United States, 23 Creighton L Rev 97 (1990) (detailing courts' vacillation).

${ }^{4}$ See United States $v$ Walters, 997 F2d 1219, 1222 (7th Cir 1993) (" $\mathrm{Mt}$ is no surprise that each side to [a] case can cite several of our decisions in support [of its view as to whether a mailing is for the purpose of committing a scheme to defraud].").
} 
D. A Case Study

The insightful opinion in United States $v$ Henderson illuminates a superior alternative to the current approach. ${ }^{45}$ In Henderson, the district court effectively employed repeal by implication to hold that the mail fraud statute is preempted by the more specific tax fraud statute. ${ }^{46}$ The court recognized that the mail fraud statute is a gapfiller and also that Congress had passed a subsequent statute to govern the issue at hand. ${ }^{47}$ Therefore, the Henderson court found "no need to use the mail fraud statute as a stopgap device until particularized legislation is enacted to deal directly with the evil.".48

Unfortunately, Henderson rarely persuades other courts. Two principal objections to the approach of the Henderson court have arisen, both of which break down under close examination. The first objection is that a subsequent statute does not indicate congressional intent to repeal an earlier statute. The search for intent, however, asks the wrong question. The issue is not whether "Congress has the right to authorize additional sanctions for abuse of the mails," ${ }^{49}$ or even whether there was "Congressional intent to create a hierarchy of sanctions that would preempt the applications of the mail fraud statute. ${ }^{.50}$ No one doubts Congress's power to do the former, and if the latter were true, there would be express repeal. The relevant question is how to construe silence. Construing silence to mean implicit repeal minimizes the cost to Congress of exempting conduct from criminality.

The second attack on Henderson is that sometimes Congress intends for two criminal statutes to govern the same conduct. Courts voicing this opinion rely on United States $v$ Batchelder. ${ }^{51}$ In Batchelder, the defendant had been convicted of violating 18 USC $\S 922(\mathrm{~h})$, which prohibits a felon from receiving a firearm that has traveled through interstate commerce. ${ }^{52}$ The defendant was sentenced to five years in accordance with 18 USC $\S 924 . .^{53}$

4386 F Supp 1048 (S D NY 1974). See also Ellen S. Podgor, Tax Fraud-Mail Fraud: Synonymous, Cumulative or Diverse?, 57 U Cin L Rev 903 (1989) (discussing Henderson and related cases).

${ }^{4} 386$ F Supp at 1053-54.

4 Id.

${ }^{4}$ Id (internal quotations omitted).

${ }^{49}$ United States $v$ Weatherspoon, 581 F2d 595, 600 (7th Cir 1978).

${ }^{83}$ Id at 599.

442 US 114 (1979). See also United States v Simon, 510 F Supp 232, 236-37 (E D Pa 1981).

422 US at 116.

"3 Id. 
An alternate statutory provision, 18 USC $\S 1202(a)$, was identical to $\S 922$ as applied to a convicted felon who unlawfully received a firearm. ${ }^{54}$ This alternate provision provided for a maximum sentence of two years. ${ }^{55}$ The defendant argued that this overlap meant that $\S 1202$ implicitly repealed $\S 924 .{ }^{56}$

The Supreme Court rejected this argument. ${ }^{57}$ It relied heavily on the fact that the scope of these two statutes was unambiguous; these were fully specified statutes. ${ }^{58}$ Moreover, the legislative history of the statutes explicitly recognized the overlapping provisions. ${ }^{59}$

Batchelder is completely unlike cases involving the mail fraud statute. First, because it involved specific statutes, there was no danger of lack of notice, and therefore no tension with rule of law values. Second, Congress had explicitly considered dual enforcement. ${ }^{60}$ In the mail fraud context, however, Congress likely did not consider such dual application of the subsequent statute and the mail fraud statute. ${ }^{61}$ Thus, Batchelder should not apply to cases involving the mail fraud statute.

This Part has shown the incoherence of the current approach to the mail fraud statute, as exemplified by the first three cases, and contrasted it with the superior results obtained by repeal by implication, as exemplified by Henderson. The next Part attempts to diagnose the problem plaguing current law.

\section{THE Misunderstood MAIL FraUd STATUTE}

The central premise of this Comment is that courts fundamentally misunderstand the mail fraud statute. This misunderstanding manifests itself in the form of courts adopting two in-

${ }^{54} 18$ USC $\S 1202(a)(1994)$.

${ }^{25}$ Id.

${ }^{56}$ Batchelder, 442 US at 117.

${ }^{57}$ Id at 123.

${ }^{5}$ Id. Specified statutes regulate a clearly delineated set of activities and require courts only to act as Congress's agents in enforcing them; they differ from general statutes, such as the mail fraud statute, that regulate an undefined range of activities and require courts to "make law" in defining their scope.

${ }^{59}$ Id at 120-21.

${ }^{\infty}$ Id at 119.

${ }^{61}$ It would have been generally impossible for Congress to consider the subsequent statute when it passed the mail fraud statute. At the time of the passage of the mail fraud statute, many of the forms of fraud now captured by that statute were inconceivable. See Henderson, 386 F Supp at 1052 ("Realistically, it is somewhat of a fiction to speak of whether Congress 'intended' the mail fraud statute to apply to [tax fraud]."). See also text accompanying notes 64-66. Congress intends that the mail fraud statute act as a "stopgap device to deal on a temporary basis with the new phenomenon, until lit can develop and pass] particularized legislation ...." United States $v$ Maze, 414 US 395, 405-06 (1974) (Burger dissenting). 
consistent stances when asked to interpret the mail fraud statute. When asked to expand the reach of the mail fraud statute to capture some new form of fraud, they willingly make new law in the guise of "interpreting" the mail fraud statute. In contrast, courts mistakenly retreat to the role of Congress's agent when asked to restrict the mail fraud statute. This schizophrenic treatment of the statute has resulted in ever-expanding, nevercontracting liability.

Statutes come in two varieties, calling on courts to play two different roles: specified statutes, which require courts to act simply as passive agents of Congress, and unspecified statutes, such as the mail fraud statute, that effectively enlist courts in making law. ${ }^{62}$ Since its inception, the mail fraud statute has been broad, and every substantive congressional amendment to it has further broadened its scope. ${ }^{63}$ This breadth has enabled courts to create new crimes based upon the statute. For example, prior to the passage of the 1933 Securities Act, courts used the mail fraud statute to capture securities fraud. ${ }^{64}$ Similarly, courts have extended the mail fraud statute to credit card fraud ${ }^{65}$ and tax fraud. ${ }^{66}$ Yet courts-so ready to make law when augmenting the mail fraud statute-suddenly become dutiful, humble congressional agents when asked to restrict it and claim that "nothing ... reflect[s] any Congressional intent ... [to] preempt the application of the mail fraud statute." ${ }^{\prime 67}$ This dual treatment of the mail fraud statute makes it increasingly expansive.

62 See Kahan, 1994 S Ct Rev at 351-56 (cited in note 16) (showing how broad statutes act as implicit delegations to courts to make law). See also Chevron USA Inc $v$ NRDC, 467 US 837, 843-44 (1984) (holding that courts will defer to reasonable agency interpretations of ambiguous statutes). The Sherman Act is the paradigm example of the latter type of statute. See 15 USC $\$ \S 1$ et seq (1994); National Society of Professional Engineers $v$ United States, 435 US 679, 688 (1978) (citations omitted) (recognizing that Congress effectively asked courts to create a common law of antitrust).

${ }^{6}$ Some criminals evaded the reach of the mail fraud statute by using private carriers. Because by its terms the statute covered only the United States postal system, Congress had to act to reach this particular form of evasion. See generally Peter J. Henning, Maybe It Should Just Be Called Federal Fraud: The Changing Nature of the Mail Fraud Statute, 36 BC L Rev 435, 476 (1995) (detailing the passage of the provision to reach those who use private carriers). See also Jed S. Rakoff, The Federal Mail Statute (Part I), 18 Duquesne L Rev 771 (1980).

"Arthur F. Mathews, Criminal Prosecutions Under the Federal Securities Laws and Related Statutes: The Nature and Development of SEC Criminal Cases, 39 Geo Wash L Rev 901, 911 (1971) (citations omitted). See, for example, United States $v$ Brown, 5 F Supp 81 (S D NY 1933).

${ }_{65}$ United States $v$ Kelem, 416 F2d 346, 350 (9th Cir 1969).

${ }^{60}$ United States $v$ Mangan, 575 F2d 32, 48-49 (2d Cir 1978).

${ }^{67}$ United States $v$ Weatherspoon, 581 F2d 595, 599 (7th Cir 1978). 


\section{A. A Delegation of Lawmaking Powers to Courts}

The congressional response to McNally $v$ United States offers strong evidence of Congress's desire that courts treat the mail fraud statute as a delegation of lawmaking power ${ }^{68}$ In $M c N a l l y$, the Supreme Court, invoking the rule of lenity, created a theory of mail fraud in order to limit the scope of the mail fraud statute. ${ }^{69}$ The Court found that "the original impetus behind the mail fraud statute was to protect the people from schemes to deprive them of their money or property," that the statute covered deprivations of honest services.

Justice Stevens recognized that the Court's holding was inconsistent with the mail fraud statute's role as a gapfiller. $\mathrm{He}$ wrote that the "mail fraud statute [was] written in broad language on the understanding that the courts would have wide latitude in construing [it] to achieve the remedial purposes that Congress had identified." In other words, the Court's majority opinion destroyed the most important attribute of the mail fraud statute: its ability to adapt and capture new forms of fraud.

Congress agreed with Justice Stevens. It legislatively overturned McNally with 18 USC $\S 1346$, restoring the law to its status before the decision. ${ }^{72}$ More importantly, Congress sent a

${ }^{63}$ Some would object that courts should always confine themselves to the role of agent. Anyone who seriously believes this should advocate striking down the mail fraud statute as overbroad. No principled distinction can be drawn between delegated lawmaking in expanding the mail fraud statute-which courts currently do-and delegated lawmaking in restricting it-which courts refuse to do. Moreover, many criminal laws generally would be unconstitutional. Yet few have argued that the mail fraud statute is unconstitutional, and the day for that argument has passed. See Badders $v$ United States, 240 US 391, 393-94 (1916) (finding the mail fraud statute constitutional). For the argument that it is unconstitutional, see Moohr, 31 Harv $J$ Leg at 187-99 (cited in note 12).

${ }^{6} 483$ US 350, 359-60 (1987). See also United States v Bass, 404 US 336, 347 (1971) ("A $\mathrm{A}] \mathrm{mbiguity}$ concerning the ambit of criminal statutes should be resolved in favor of lenity .... [W] [Wen choice has to be made between two readings of what Congress has made a crime, it is appropriate, before we choose the harsher alternative, to require that Congress should have spoken in language that is clear and definite.") (citations omitted).

${ }_{70} \mathrm{McNally}, 483 \mathrm{US}$ at 356. If the Court were serious about limiting the scope of the mail fraud statute to Congress's intent at the time of passage, then the statute would be much narrower indeed. It would not reach many of the kinds of conduct the statute currently outlaws. See text accompanying notes $62-66$. For example, the mail fraud statute could cover neither tax fraud nor credit card fraud, because neither existed at that time. The Court explicitly rejected the argument respecting credit card fraud in Maze: "The mail fraud statute, first enacted in $1872, \ldots$ while obviously not directed at credit card frauds as such, is sufficiently general in its language to include them if the requirements of the statute are otherwise met." 414 US at 399 n 4.

${ }^{71} \mathrm{McNally}, 483$ US at 372-73 (Stevens dissenting).

${ }^{72}$ See 18 USC $\$ 1346$ (1994) ("For purposes of this chapter, the term "scheme or artifice to defraud' includes a scheme or artifice to deprive another of the intangible right of honest services."). 
strong signal to the courts not to hinder the mail fraud statute's capacity as the "first line of defense."

McNally reveals that Congress intends the broad language of the mail fraud statute to act as a delegation of lawmaking power to courts.

\section{B. A Demonstration of the Diagnosis}

This Part has maintained that courts misunderstand the mail fraud statute. When asked to restrict it, they erroneously adopt the role of agent, despite the fact that the statute delegates lawmaking power to courts. This Section will attempt to demonstrate the accuracy of this diagnosis with United States $v$ Bryan. ${ }^{74}$

In Bryan, the Fourth Circuit found liability under the mail fraud statute while rejecting the misappropriation theory of securities fraud-despite the fact that both statutes created uncertain liability. The court recognized that its ruling created inconsistency in the scope of federal fraud statutes, but was "not concerned" because it reasoned that fraud had different meanings in different statutes. ${ }^{75}$

The Bryan court recognized that $\S 10(\mathrm{~b})$ of the Securities Act could accommodate misappropriation theory. ${ }^{76}$ Like the mail fraud statute, $\S 10(\mathrm{~b})$ and the corollary Rule $10 \mathrm{~b}-5$ are very broad. As noted, statutes of such breadth effectively delegate lawmaking power to courts. ${ }^{77}$ The Bryan court observed that "the language of the Rule, if not of the statute, could plausibly accommodate the misappropriation theory. ${ }^{978}$ It rejected misappropriation theory, however, because it believed that securities

\footnotetext{
${ }^{3}$ Maze, 414 US at 405-06 (Burger dissenting). For another example of congressional desire to maintain a broad mail fraud statute, see note 63 .

"58 F3d 933 (4th Cir 1995).

is Id at 952.

${ }^{*}$ Id at 945.

7 Commentators have noted that "when the statute and rule are [as vague as] § 10(b) and Rule $10 \mathrm{~b}-5$... the law is surely as much judge-made as is the classic common law of the state." Louis Loss and Joel Seligman, 7 Securities Regulation 3488-89 (Little, Brown 3d ed 1991). Judge Friendly identified $\S 10(\mathrm{~b})$ and Rule 10b-5 as "significant steps toward the development of a federal common law of corporate responsibility." Judge Henry J. Friendly, In Praise of Erie - and of the New Federal Common Law, 39 NYU L Rev 383, 413-14 (1964).

${ }^{7}$ Bryan, 58 F3d at 945 (citations omitted). The sentence could be read to state that the statute could not plausibly accommodate misappropriation theory. I think, however, that the subsequent citations indicate that Judge Luttig meant that both could accommodate misappropriation theory.
} 
markets are fragile and such amorphous liability would be inappropriate. ${ }^{79}$

Despite the court's recognition of the power to control the scope of $\S 10(\mathrm{~b})$, it failed to see its concomitant power to control the scope of the mail fraud statute. The court noted that " $[\mathrm{m}] \mathrm{uch}$ of the conduct rendered criminal under the misappropriation theory is already criminalized . . . under mail and wire fraud statutes." ${ }^{300}$ If the court had understood that it had the power to restrict the scope of the mail fraud statute, it seems likely that it would have rejected criminal liability under the mail fraud statute for the very same reason it rejected misappropriation theory. The "securities markets demand certainty," and amorphous criminal liability - be it under $\S 10(b)$ or the mail fraud statutechills valuable conduct in the securities realm.

The Bryan court failed to see this because it too quickly assumed the role of an agent, merely complying with orders and not concerning itself with inconsistencies in those orders. While such concerns usually reside with the principal, in the case of the mail fraud statute, Congress has enlisted the courts to step beyond the role of agent and exercise judgment. Were courts to recognize this fact, they would properly address questions such as the inconsistency in rejecting misappropriation theory while convicting for mail fraud.

Having diagnosed the problems with the current approach to the mail fraud statute, this Comment now turns to prescribing the appropriate remedy. Repeal by implication, a tool of statutory interpretation, solves the problem of schizophrenic treatment of the mail fraud statute.

\section{THE CASE FOR REPEAL BY IMPLICATION}

Repeal by implication offers an effective tool to restrict the mail fraud statute while preserving the statute's role as a gapfiller. This Part first explains why repeal by implication cures the courts' schizophrenic treatment of the mail fraud statute. It then turns to the caselaw to demonstrate that precedent offers some support for the use of repeal by implication. Finally, it discusses the problem of how to determine the scope of implicit repeal and

\footnotetext{
79 The court also relied heavily on Supreme Court precedent. Id. This precedent, however, is hardly dispositive on the issue, as the Supreme Court itself split on the question of misappropriation theory under the Securities Act in a four-four vote. See Carpenter $v$ United States, 484 US 19, 24 (1987). The Fourth Circuit's choice of precedent, therefore, reveals something of its belief as to the superior policy.

${ }^{80}$ Bryan, 58 F3d at 953.
} 
suggests that courts can solve this problem by tying the scope of the implicit repeal to the scope of the statute.

\section{A. Policy Arguments for Repeal by Implication}

Repeal by implication is the best means of limiting the mail fraud statute for four reasons. It lowers the cost to Congress of enacting criminal legislation, restricts judicial and prosecutorial discretion, improves notice, and preserves the gapfiller status of the mail fraud statute.

\section{Increasing Congress's power to shape criminal law.}

Repeal by implication would increase the power of Congress to shape the criminal law because it would lower Congress's cost of signaling to courts its preference for implicit repeal, and enhance the legislative judgments embodied in statutory gaps.

Repeal by implication would reduce the cost of legislating when measured against the unnecessary costs created by the current approach to the mail fraud statute. The current approach creates two such costs. Congress has to expend scarce resources to consider and indicate when it does not want the mail fraud statute to supplement a subsequent statute. This is expensive: so expensive, in fact, ${ }^{81}$ it is likely that Congress does not even consider the issue in most cases. Of course, repeal by implication would force Congress to indicate when it wants dual application. Therefore, we can minimize the costs by adopting a presumption that mirrors what Congress would want in the majority of cases. ${ }^{82}$

Congress would most likely prefer implicit repeal as a default rule in the case of specific criminal statutes. ${ }^{83}$ Congress cre-

\$1 See Isaac Ehrlich and Richard A. Posner, An Economic Analysis of Legal Rulemaking, $3 \mathrm{~J}$ Legal Stud 257, 267 (1974) ("L]egislative production [is] an extremely expensive form of production [of legal rules].").

See id at 267-68 (" $[\mathrm{A}] \mathrm{s}$ the amount and complexity of social activity increase over time, we can expect to find that legislatures . . . will delegate more and more of the legislative function ... to executive and administrative agencies and courts-as has in fact happened.").

${ }^{3}$ Although no precedent on point exists, courts should also find implicit repeal in the case of a subsequent, general statute. Consider securities fraud. A general provision such as $\$ 10(\mathrm{~b})$ acts as a delegation to courts (or the SEC) to fashion law governing securities fraud. When courts create gaps through their interpretations of this law, the mail fraud statute should not fill those gaps. If courts think a gap should not exist, they can use $\S 10(b)$, the subsequent statute, to fill the gap. Such an approach would better serve the value of notice by uniting all the relevant law on securities fraud under $\$ 10(\mathrm{~b})$ and related securities statutes, and consequently increase efficiency in criminal law by reducing the number of applicable statutes. Moreover, while the principle of respecting congressional judgment no longer holds, there is no reason why courts should not respect their 
ates gaps in such statutes for one of two reasons. It may determine that the conduct does not warrant the use of federal resources. For example, the minimum of five thousand dollars in the credit card fraud statute reflects a congressional judgment that fraud below that amount is not worth pursuing. ${ }^{84}$ Alternatively, Congress-when legislating in a sensitive area-may specify carefully what is illegal and what is not. This specification creates deliberate gaps in the statute. To fill these gaps would undo Congress's careful specification, ultimately preventing Congress from implementing its judgments without the additional costly step of indicating that it does not want enforcement by means of two statutes. This logic informed the Supreme Court's ruling in Dowling $v$ United States that the Court would not "presume[ ] congressional adoption of an indirect but blunderbuss solution to a problem treated with precision when considered directly [by Congress]. ${ }^{385}$ Under either rationale, assuming that Congress intends dual enforcement undermines the congressional judgment captured in the statutory gap and unnecessarily increases the cost of legislating.

In contrast, the argument that Congress prefers dual enforcement is far less persuasive. If Congress wanted federal criminal law to apply, it would not take the costly step of creating a statutory gap. It defies reason to suggest that Congress created a gap because it thought that the heavy-handed mail fraud statute offered a better approach. Courts would minimize the cost of lawmaking for Congress by adopting implicit repeal as the default rule. ${ }^{86}$

One objection to this argument for repeal by implication comes from Justice Scalia. When he was a judge on the D.C. Circuit Court of Appeals, Scalia argued that repeal by implication

own judgments. Outside of cases involving specific statutes where courts are merely legislative agents-a characterization that does not apply in the case of the mail fraud statute-it is hard to discern any principle supporting the lack of "concern[ ] with any inconsistency in the scope of fraud prohibited by ... various statutes." Bryan, 58 F3d at 952.

${ }^{84}$ See text accompanying notes $34-38$.

ss 473 US 207, 226 (1985).

${ }^{86}$ One might ask why Congress itself does not pass a repeal by implication bill detailing when courts should and should not implicitly repeal the mail fraud statute. Simply put, lawmaking is very expensive for Congress, and such a law is not worth its time. See Ehrlich and Posner, $3 \mathrm{~J}$ Legal Stud at 273-74 (cited in note 81) ("[T] he marginal cost of statutory rules exceeds that of judge-made rules. ... The greater costs of statutory rules may also explain why such rules are generally more difficult to revise or modify than judge-made rules."). The costs of such an endeavor would include surveying the criminal code and deciding on a statute-by-statute basis whether or not the mail fraud statute should be repealed in those areas. Even if Congress confined the bill to a presumption of implicit repeal, the cost of legislating would probably not outweigh the benefits. In contrast, courts could very cheaply adopt this presumption. 
would make lawmaking too difficult for Congress because legislators would constantly be forced to guess how a current bill might reshape existing law. ${ }^{87} \mathrm{We}$ can understand this objection to be saying that lawmaking is already expensive for Congress, and repeal by implication could create huge additional costs by forcing Congress to gauge the impact of a new law on old ones. Two responses defeat this objection. First, this Comment has already shown that repeal by implication would likely reduce the cost of lawmaking. Second, Scalia's point responds to an argument that repeal by implication should apply generally. This Comment is arguing for repeal by implication just in the case of mail fraud, greatly diminishing any difficulty repeal by implication might create for Congress.

\section{Reducing judicial and prosecutorial discretion.}

Repeal by implication would also limit judicial and prosecutorial discretion. This limitation would preserve their status as subordinates to Congress in making law, as contemplated by the Constitution. ${ }^{88}$

Judged against the baseline of current law, repeal by implication would better limit judicial (and prosecutorial) discretion. A court's ruling that the mail fraud statute is implicitly repealed would bind or at least persuade future courts and prosecutors.

First, one has to consider the baseline against which one is judging repeal by implication-the current approach, under which courts and prosecutors already have substantial discretion. Judges exercise discretion in augmenting the scope of the mail fraud statute. Courts have no explicit guidelines from Congress for deciding whether the mail fraud statute captures a new form of illicit conduct.

Second, the Supreme Court's vacillation on the purpose requirement in the mail fraud statute creates discretion. ${ }^{89}$ Under the current approach, the caselaw gives courts unclear instructions regarding what satisfies the mailing element. Such a range

${ }^{67}$ United States $v$ Hansen, 772 F2d 940, 944 (DC Cir 1985) (Repeal by implication would "distort [ ] [the legislative process] by a sort of blind gamesmanship, in which Members of Congress vote for or against a particular measure according to their varying estimations of whether its implications will be held to suspend the effects of an earlier law that they favor or oppose."). See also Stephen F. Ross, Where Have You Gone, Karl Llewellyn? Should Congress Turn Its Lonely Eyes to You?, 45 Vand L Rev 561, 572-73 (1992) (" $[\mathrm{A}]$ busy Congress of limited prescience might fully support judicial use of this canon [disfavoring repeals by implication], precisely to avoid the political embarrassment of accidentally repealing desirable legislative provisions.").

"US Const, Art I, $\$ 1$.

See text accompanying notes $33-44$. 
of inconsistent choices permits courts to find liability case by case, not on the basis of meaningful distinctions-such as whether Congress intended to outlaw the conduct-but rather on such considerations as whether distance or a slow postal system caused a delay in the mailings.

In practice, courts consistently refuse to exercise their power to limit the statute. This refusal shifts the discretion to prosecutors, who gladly accept this power. One Assistant United States Attorney described "the mail fraud statute [as] our Stradivarius, our Colt 45, our Louisville Slugger, our Cuisinart-and our true love." Prosecutors inherit the power to shape the law by choosing whether to bring mail fraud charges to fill a statutory gap created by Congress. This shift in the locus of discretion runs counter to the notion of public accountability because a prosecutor's decisions are far less visible than a court's. We never know when a prosecutor decides not to bring a charge of mail fraud.

In contrast, if a court ruled that a subsequent statute implicitly repealed the mail fraud statute, that decision would bind future courts and prosecutors. This approach would limit their discretion and force courts to make visible decisions as to the scope of the mail fraud statute.

\section{Rule of law.}

There exists a "constitutional requirement of definiteness [, which] is violated by a criminal statute that fails to give a person of ordinary intelligence fair notice that his contemplated conduct is forbidden by [a] statute." ${ }^{11}$ Repeal by implication would enhance notice by using subsequent statutes to carve out pockets in the mail fraud statute. The subsequent statutes would improve notice by alerting citizens to the federal treatment of specific types of criminal conduct. For example, if the credit card fraud statute implicitly repealed the mail fraud statute, citizens would know that the federal government would not prosecute such frauds below five thousand dollars. ${ }^{92}$

The broad language of the mail fraud statute fails to identify what conduct it outlaws. A defender of the current approach to the statute might claim that the statute facially covers all situations, so notice is always given. He would maintain that the language is broad but not vague. ${ }^{93}$ In this case, however, the mail

\footnotetext{
90 Rakoff, 18 Duquesne L Rev at 771 (cited in note 63).

${ }^{91}$ United States $v$ Harris, 347 US 612, 617 (1954).

${ }^{92}$ See text accompanying notes 34-38.

${ }^{93}$ See Maze, 414 US at 408 (White dissenting) (characterizing the mail fraud statute as "an unambiguous federal criminal statute"). See also Dowling, 473 US at 232 (Powell
} 
fraud statute's breadth indicates vagueness. It requires only that an individual lie in a letter in an attempt to get money or property. For example, suppose a boy away at camp lies to his mother about winning the soccer match because he knows she will send him a batch of cookies. While he has technically committed mail fraud, no prosecutor would charge the child for lying to his mother in a letter. Therefore, prosecutorial discretion effectively makes the scope of the mail fraud statute ambiguous. Citizens are thus left to guess what conduct the mail fraud statute actually prohibits. ${ }^{94}$

Courts might apply the rule of lenity to restrict the mail fraud statute and give citizens better notice about the scope of conduct that it covers, but the rule is too blunt an instrument to restrain the mail fraud statute. For the rule of lenity to narrow a statute, a court must be able to choose between two interpretations, one narrower than the other. Discerning a narrower interpretation of the mail fraud statute, however, requires a court to devise a positive theory of mail fraud, which would limit the statute's ability to cover emerging forms of fraud. ${ }^{95}$ Because the rule of lenity thus would frustrate the mail fraud statute's gapfiller function, courts have been properly reluctant to apply it. ${ }^{96}$

Repeal by implication provides citizens with some notice but in an unconventional way. Most statutes provide citizens with notice by defining the scope of conduct that is prohibited. Repeal by implication does not define the scope of prohibited conduct. Instead, repeal by implication uses subsequent specific statutes to define what conduct has not been outlawed. ${ }^{97}$

Although repeal by implication would better ensure notice, it does not resolve the inherent tension between the mail fraud statute and the rule of law. The role of the mail fraud statute as a gapfiller alters the common law presumption that conduct is legal unless the law clearly states otherwise, for its broad language effectively presumes that conduct is illegal. While the re-

dissenting) ("As I read [the statute at hand], it is not ambiguous, but simply very broad.").

* See United States v McNeive, 536 F2d 1245, 1248 (8th Cir 1976) ("Courts . . . have been required to discern the purpose and reach of $\$ 1341$ from the broad, unqualified language of the statute itself [because of the lack of legislative history].") (citation omitted).

"5 For a discussion of "positive theory," see note 13.

See Kahan, $1994 \mathrm{~S}$ Ct Rev at 346 (cited in note 16). There have been many recent commentaries on the rule of lenity and its (non)application. See, for example, Ross E. Davies, Comment, A Public Trust Exception to the Rule of Lenity, $63 \mathrm{U}$ Chi L Rev 1175 (1996) (demonstrating the unstated exception to the rule of lenity in cases involving violations of the public trust); Sarah Newland, Note, The Mercy of Scalia: Statutory Construction and the Rule of Lenity, 29 Harv CR-CL L Rev 197, 228 (1994) (calling for more consistent application of the rule of lenity).

${ }^{57}$ For a discussion of how to define the scope of the repeal, see Part III.C. 
versal of this presumption seems to be an unfortunate, unavoidable byproduct of gapfillers, there is some evidence that courts will recognize mistake of law defenses when the underlying conduct is not morally reprehensible. ${ }^{98}$ The next Section defends this shift in presumption.

\section{Retaining the flexibility of the statute.}

Repeal by implication is superior to other attempts to limit the mail fraud statute because it preserves the statute's role as a gapfiller in two ways. First, repeal by implication lowers the cost of outlawing illicit behavior. Second, it deters opportunistic criminals from trying to find loopholes in statutes. ${ }^{99}$

If one asks what the optimal distribution of criminal lawmaking power among the different branches is, the first argument for a gapfiller becomes clear. Lawmaking is very costly for Congress. ${ }^{100}$ By passing a broad statute, Congress has delegated the responsibility of making law to a different institution, be it the executive branch or the judiciary (for which the costs are much lower)..$^{101}$ Congress expresses a general purpose and relies on one of the other branches to fill in the details.

The second reason for a gapfiller stems from the fact that criminal conduct takes many forms. If Congress completely specified the scope of fraud, the criminal justice system would be unable to stop those who engage in illicit conduct without violating the precise provisions of the law. ${ }^{102}$ By not specifying, Congress

See Michael L. Travers, Comment, Mistake of Law in Mala Prohibita Crimes, 62 U Chi L Rev 1301, 1303-16 (1995) (discussing cases allowing the mistake of law defense). See also Kahan, $1994 \mathrm{~S} \mathrm{Ct}$ Rev at 399-405 (cited in note 16) (arguing that broad statutes do not heavily impinge on the value of notice).

${ }^{9}$ One powerful yet intellectually unsatisfactory rationale is that we should simply accept the existence of this gapfiller as a given, since we have long had it. The mail fraud statute is over one hundred years old, and before that, courts used the generic crime of fraud as a gapfiller. Justice Story defined fraud as "all acts . . . which involve a breach of legal or equitable duty . . . and [which] are injurious to another, or by which an undue and unconscientious advantage is taken of another." Story, 1 Equity Jurisprudence $\$ 186$ at 190 (cited in note 6). Indeed, the history of the mail fraud statute shows that every time the courts erect a limit to the scope of the statute, Congress removes the limitation. See generally Rakoff, 18 Duquesne L Rev 771 (cited in note 63). But surely this assertion does not satisfy. Gapfillers persist because there is good reason for them.

${ }^{100}$ See Kahan, 110 Harv L Rev at 474-75 (cited in note 9) (explaining that legislating is extremely costly for Congress). See also Colin S. Diver, The Optimal Precision of Administrative Rules, 93 Yale L J 65, 103 (1983) (noting that high enforcement costs are external to the legislature, which "helps to explain why legislatures customarily use openended language to embody their substantive commands"); Ehrlich and Posner, $3 \mathrm{~J}$ Legal Stud at 267-71 (cited in note 81) (identifying costs to making legal rules).

${ }^{101}$ See Kahan, 110 Harv L Rev at 473-74 (cited in note 9).

${ }^{102}$ See note 63. 
encourages courts to adapt the mail fraud statute to reach such opportunistic criminal behavior. This deliberate ambiguity greatly reduces the cost of stopping illegal conduct and discourages criminals from attempting to shape their behavior to slip through gaps in specified criminal law.

\section{B. Repeal by Implication Under Current Law}

Despite the harsh rhetoric of current law ${ }^{103}$ and some hostile precedents, ${ }^{104}$ caselaw offers some support for repeal by implication.

Precedent strongly backs the proposition that a subsequent, specific statute implicitly repeals a general, preceding statute. ${ }^{105}$ Courts find implicit repeal in such cases because the legislator has directed her attention to the specific conduct at hand. ${ }^{106}$ This

\footnotetext{
${ }^{103}$ See Posadas v National City Bank, 296 US 497, 503 (1936) ("[R]epeals by implication are disfavored."). See also Wood $v$ United States, 41 US 342, 363 (1842) (There can be repeal by implication only when there is "a positive repugnancy between the provisions of the new law, and those of the old; and even then the old law is repealed by implication only pro tanto to the extent of the repugnancy."). At other times, the Court has proclaimed that the intent to repeal "must be clear and manifest." Red Rock $v$ Henry, 106 US 596,602 (1883). Such a requirement makes cases of repeal by implication a null set; the term for "clear and manifest" intent is express. Note that the rhetoric of these cases is more rigid than the reality of the caselaw.

${ }^{10}$ The Supreme Court has explicitly rejected repeal by implication in the case of securities fraud. Edwards $v$ United States, 312 US 473, 483-84 (1941) ("We see no basis for a conclusion that Congress intended to repeal the [mail fraud] statute.").

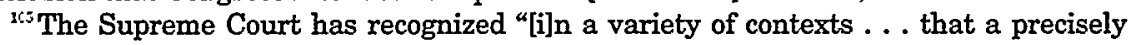
drawn, detailed statute pre-empts more general remedies." Brown v General Services Administration, 425 US 820, 834 (1976) (citations omitted). Indeed, some cases favor the "principle that a more specific statute will be given precedence over a more general one, regardless of their temporal sequence." Busic v United States, 446 US 398, 406 (1980). But see United States v Bennerson, 616 F Supp 167, 175 n 6 (S D NY 1985) (In Busic and Simpson, the Supreme Court "relied . . . upon ... express indications in the legislative history that the general statute was not to be applied when the specific statute was available."). The Court did use legislative history in Busic, but it also based its holding on "relevant canons of statutory construction." Busic, 446 US at 404 . Repeal by implication was one of these "relevant canons."

${ }^{116}$ Radzanower $v$ Touche Ross \& Co, 426 US 148, 153 (1976) (In such a case, the legislator has "focus[ed] on the particularized problem[ ]."). Note that a subsequent general statute will not preempt a prior specific statute. Id ("It is a basic principle of statutory construction that a statute dealing with a narrow, precise, and specific subject is not submerged by a later enacted statute covering a more generalized spectrum."). But the case here is the converse. This Comment argues that a subsequent specific statute should implicitly repeal a prior general statute. Indeed, one could enlist the argument for the first proposition to make the case for the second. See also id at $159 \mathrm{n} 2$ (Stevens dissenting) (noting the general assumption that "[t]he legislature's attention was probably focused more directly on the subject matter of the specific than on only one aspect of a much broader subject matter"). Independent of this observation, Justice Stevens seems to favor case-by-case decisionmaking. He finds "abstract reasoning [ ] less instructive than a consideration of the source and the need for the alleged conflict." Id at 160. To decide the particular case, "[o]f special importance is an evaluation of the intent of Congress when it
} 
reasoning is consistent with this Comment's earlier discussion of why Congress creates gaps in a subsequent statute. ${ }^{107}$ When enacting the subsequent statute, Congress focuses its attention and makes refined judgments as to what conduct it does and does not want outlawed. By filling these gaps with the mail fraud statute, courts block that judgment.

Courts also recognize that finding implicit repeal serves the value of notice. In one case, the Supreme Court explicitly linked implicit repeal with the rule of lenity. ${ }^{108}$ As discussed above, in the case of the mail fraud statute, repeal by implication would actually serve the value of notice better than the (unapplied) rule of lenity. ${ }^{109}$ Unlike the rule of lenity, repeal by implication provides notice while at the same time preserving the mail fraud statute as a gapfiller.

Some courts reject repeal by implication and argue that it is inconsistent with congressional intent. ${ }^{110}$ Such an argument is misguided in the case of the mail fraud statute for two reasons. First, one might respond that Congress never intended for the mail fraud statute to cover the conduct at issue. Second, the focus on intent relegates the court to the role of an obedient congressional agent rather than recognizing that Congress intended courts to make law with the mail fraud statute. ${ }^{111}$

enacted the[ ] statutes." Id. What, then, is the intent of the mail fraud statute? If it simply is to act as a gapfiller, then repeal by implication is consistent with congressional intent, for there is no longer a gap to fill. It should also be noted that in Radzanower the Supreme Court found no implicit repeal. Id at 155 (majority opinion). That fact should not discount its characterization of the caselaw.

${ }^{107}$ See text accompanying note 17.

${ }^{109}$ Simpson v United States, 435 US 6, 15-16 (1978) (This "principle is a corollary of the rule of lenity, an outgrowth of our reluctance to increase or multiply punishments absent a clear and definite legislative directive."). While it is true that the Court noted favorable legislative history, it also stated that the "sparse," id at 15, legislative history was "not dispositive," id at 13, on the issue. The Court later characterized its holding as resting upon "the legislative history and applicable canons of statutory construction," Busic, 446 US at 403 , suggesting that repeal by implication may be employed as a tool of statutory interpretation.

${ }^{109}$ See text accompanying notes $91-97$.

${ }^{110}$ See United States v Simon, 510 F Supp 232, 236-37 (E D Pa 1981) ("[D]efendant has failed to identify either language [in the statute] or any part of its legislative history which would support [a finding of congressional intent to repeal]."). See also Bennerson, 616 F Supp at $175 \mathrm{n} 6$ (In cases where the Supreme Court found implicit repeal, "it relied upon ... express indications in the legislative history that the general statute was not to be applied when the specific statute was available.") (citations omitted).

${ }^{111}$ See Part II. 


\section{The Scope of the Implicit Repeal}

For repeal by implication to work, courts must decide the extent to which a subsequent statute implicitly repeals the mail fraud statute. To do so, courts should match the scope of the repeal to the scope of the subsequent statute. ${ }^{112}$

Matching implicit repeal to the scope of the subsequent statute does not mean that one should find implicit repeal only when charges can be brought under another statute. The latter approach would swallow repeal by implication, as prosecutors could always use the mail fraud statute to fill statutory gaps that prevented them from bringing charges. Take Maze as an example. ${ }^{113}$ In that case, the prosecutor could not bring a charge of credit card fraud because the amount of money involved fell below the minimum in the credit card statute. ${ }^{114}$ The mail fraud statute should not apply, however, because Congress deliberately created this gap in the statute.

To match the scope of implicit repeal to the scope of the subsequent statute, courts must first decide the scope of the subsequent statute. Guidelines in this endeavor are notably absent from both caselaw and commentary. ${ }^{115}$ This absence probably exists because formulating theoretical guidelines seems exceedingly difficult. ${ }^{116}$

The lack of theoretical guidance is not troublesome, however. In practice courts are able to determine the scope of a statute to their own satisfaction, ${ }^{117}$ so determining the scope of repeal

\footnotetext{
${ }^{112}$ Under this rule, repeal by implication would actually have its greatest impact in the case of such broad, general statutes as the Sherman Act, 15 USC $\$ 1$ et seq (1994), and the National Stolen Property Act, 18 USC $\$ 2314$ (1994). These acts treat their respective areas comprehensively, obviating the need for the mail fraud statute to fill gaps.

${ }^{113}$ See text accompanying notes $33-42$.

${ }^{11}$ See text accompanying note 36.

${ }^{125}$ See Frank H. Easterbrook, Statutes' Domains, 50 U Chi L Rev 533, 533 (1983) ("When does a court ... hold [a statute] inapplicable ... ? This question has received almost no attention from courts or scholars."). See also Larry Kramer, Rethinking Choice of Law, 90 Colum L Rev 277, 280-81 (1990) (" $[$ [H] ow does one know when more than one law may apply? Choice of law scholars have ignored this question."). This lacuna in choice of law scholarship and caselaw probably exists because courts decide this question simply by focusing on statutes invoked by the parties, an option unavailable in the criminal context. See Easterbrook, 50 U Chi L Rev at 540.

${ }^{115}$ One might entertain healthy skepticism about whether courts will employ a commentator's theory for determining the applicability of a statute. See William N. Eskridge, Jr. and Philip P. Frickey, Statutory Interpretation as Practical Reasoning, $42 \mathrm{Stan} \mathrm{L}$ Rev $321,321-22$ (1990) ('Judges' approaches to statutory interpretation are generally eclectic, not inspired by any grand theory, and this is a good methodology.").

${ }^{117}$ See Kramer, 90 Colum L Rev at 301 (cited in note 115) ("Experience demonstrates that courts generally are able to determine the underlying purposes of laws based on language, structure, legislative history (if such history exists), and background."). This inquiry could legitimately entail analysis of legislative history. The criticism of courts that
} 
should also be fairly straightforward. ${ }^{118}$ Federal statutes frequently identify the conduct they target, for example, the National Stolen Property Act ${ }^{119}$ or the Securities Exchange Act of 1934. ${ }^{120}$ Others will reach a particular type of conduct even though they do not formally describe it. For example, the Sherman Act $t^{121}$ covers antitrust issues. ${ }^{122}$

The example of bribery shows how this approach works. Congress has specifically outlawed the bribery of grain inspectors in two statutes. ${ }^{123}$ Courts should refuse to use the mail fraud statute to supplement the prosecution of a case involving the bribery of a grain inspector because Congress has given the issue its direct attention as shown by these two statutes. But for bribery of other officials, assuming that no other statute exists, courts should use the mail fraud statute. There is no reason to suppose that the two very narrow statutes governing grain inspectors act as the definitive treatment of all cases of bribery. ${ }^{124}$ Of course, by the time a court takes into account all other subsequent statutes governing different kinds of bribery, ${ }^{125}$ the mail fraud statute should have little to say on the subject.

Courts may disagree about which statutes implicitly repeal the mail fraud statute. They will make arguments, often on policy grounds, but this outcome should not be worrisome. Courts

use legislative history to find no implicit repeal is not a criticism of using legislative history as such. The reproach is that courts asked the wrong question by focusing on intent to repeal, which would require some kind of conscious reflection by Congress about the interaction of the statute at hand and the mail fraud statute. That is different from asking whether a statute governs an area of conduct, which requires no thought whatsoever by Congress regarding the mail fraud statute.

${ }^{118}$ See Kramer, 90 Colum L Rev at 301 (cited in note 115) (" $[1]$ t is important not to overstate the difficulty of determining a law's purpose.").

${ }^{119} 18$ USC $\$ 2314$ (1994).

${ }^{1200} 15$ USC $\$ \S 78$ et seq (1994).

${ }^{121} 15$ USC $\$ \$ 1$ et seq (1994).

${ }^{122}$ In both cases, courts should strive to create uniformity, which will increase certainty in the federal criminal law. See Eben Moglen and Richard J. Pierce, Jr., Sunstein's New Canons: Choosing the Fictions of Statutory Interpretation, 57 U Chi L Rev 1203, 1207 (1990) ("The interpretive community . . . is simply the social group whose shared comprehension of a context makes possible the common interpretation of socially relevant texts. The group element is absolutely necessary to the interpretive process.") (emphasis added).

${ }^{123}$ See 7 USC $\$ \S 85$ (licensure and suspension of inspectors), 87b(a)(7) (prohibiting bribery) (1994).

${ }^{124}$ For the sake of this example, this Comment ignores the multitude of other statutes Congress has passed in this area. See, for example, 15 USC $\$ 80 \mathrm{~b}-3(\mathrm{e})(2)(\mathrm{a})$ (1994) (bribery of investment advisers); 18 USC $\$ \$ 210-11$ (1994) (bribery for the purpose of obtaining appointive office); 18 USC $\S 217$ (1994) (bribery to adjust farm indebtedness). For more examples, see Norman Abrams and Sara Sun Beale, Federal Criminal Law and Its Enforcement $225 \mathrm{n}$ a (West $2 \mathrm{~d}$ ed 1993).

${ }^{125}$ See note 124. 
will focus on and be restrained by subsequent statutes. Policy may influence a court's decision about the scope of a subsequent statute, but surely this is superior to focusing on irrelevant, hairsplitting questions, such as whether a delay in a mailing was caused by the distance or the postal system.

Repeal by implication not only preserves the gapfiller attributes of the mail fraud statute, but also refines criminal law. It lowers Congress's cost of creating statutory gaps, restricts judicial and prosecutorial discretion, and serves notice better than the (unapplied) rule of lenity, all without undermining the gapfiller function.

\section{CONCLUSION}

The mail fraud statute plays an important role in federal criminal law. Its broad scope enables it to reach novel forms of fraud and stop opportunistic criminals. But the adaptability of the mail fraud statute also enables prosecutors and courts to circumvent the subsequent enactments of Congress, and the statute's use runs counter to the principle of notice that underlies the rule of law.

When asked to limit the mail fraud statute, courts mistakenly claim that they are simply Congress's agent. Yet their willingness to make law when expanding the statute reveals that the mail fraud statute delegates lawmaking power to courts. Moreover, by overturning McNally, ${ }^{126}$ Congress demonstrated that it intends the mail fraud statute to act as a gapfiller. Repeal by implication offers a way to preserve the strength of the mail fraud statute while mitigating its weaknesses. When Congress passes a criminal statute governing particular conduct, the new statute will implicitly repeal the mail fraud statute's coverage of that conduct. Courts and prosecutors will then be forced to respect the subsequent enactment of Congress. But because repeal by implication does not rely on a particular theory of fraud to cabin the mail fraud statute, prosecutors will still have the statute-their most effective weapon against novel crimes-at their disposal.

${ }^{125} 483$ US 350 . See text accompanying notes 68-73. 
